\title{
EFFECT OF ETHANOLIC FLAX (LINUM USITATISSIMUM L.) EXTRACTS ON LIPID OXIDATION AND CHANGES IN NUTRITIVE VALUE OF FROZEN-STORED MEAT PRODUCTS
}

\author{
Katarzyna Waszkowiak ${ }^{\bowtie}$, Krystyna Szymandera-Buszka, Marzanna Hęś \\ Faculty of Food Science and Nutrition, Poznań University of Life Sciences \\ Wojska Polskiego 31, 60-624 Poznań, Poland
}

\begin{abstract}
Background. Flaxseed (Linum usitatissimum L.) is an important source of phenolic compounds, mainly lignans. Antioxidant capacities of flaxseed extracts that contain the compounds have been reported earlier. However, there is a lack of accessible information about their activity against lipid oxidation in meat products. Therefore, the effect of ethanolic flaxseed extracts (EFEs) on lipid stability and changes in nutritive value of frozen-stored meat products (pork meatballs and burgers) was determined.

Material and methods. EFEs from three Polish flax varieties (Szafir, Oliwin, Jantarol) were applied in the study. During 150-day storage of meat products, the lipid oxidation (peroxide and TBARS value) and thiamine retention were periodically monitored, alongside with methionine and lysine availability and protein digestibility.

Results. The addition of EFEs significantly limited lipid oxidation in stored meatballs and burgers. EFE from brown seeds of Szafir var. was superior to the others from golden seeds of Jantarol and Oliwin. Moreover, the extracts reduced changes in thiamine and available lysine content, as well as protein digestibility, during storage time. The effect of EFE addition on available methionine retention was limited.

Conclusion. The ethanolic flaxseed extracts exhibit antioxidant activity during frozen storage of meat products. They can be utilized to prolong shelf-life of the products by protecting them against lipid oxidation and deterioration of their nutritional quality. However, antioxidant efficiency of the extracts seems to depend on chemical composition of raw material (flax variety). Further investigations should be carried on to explain the issue.
\end{abstract}

Key words: flax seed, ethanolic extract, lipid oxidation, thiamine retention, protein nutritive value

\section{INTRODUCTION}

Lipid oxidation is a major factor that causes deterioration of meat product quality during frozen storage. The process has an adverse effect on sensor attributes and nutritive value of the products [Wąsowicz et al. 2004], and thus limits their shelf-life.
Pork is a good source of protein and an important source of thiamine. Therefore, changes in vitamin B1 content, as well as protein nutritional value (i.e. protein digestibility and essential amino acid bioavailability), should be particularly monitored in stored

\footnotetext{
*Supporting agency: the research was financial supported by National Science Centre in Poland (project no. N_N312_242438).

凶kwaszkow@up.poznan.pl
} 
pork products. For nutritional quality of the products, changes of lysine and amino acids containing sulphur are crucial, as they are exogenous amino acids which are sensitive to oxidation-induced damage [Friedman 1996]. The studies concerning the changes of thiamine content [Szymandera-Buszka 2003, Waszkowiak and Szymandera-Buszka 2006], as well as protein nutritional value [Korczak et al. 2004, Hęś et al. 2007], during storage of pork or pork products confirmed that they resulted from lipid oxidation.

Among strategies that help to reduce lipid oxidation and its negative nutritional consequences, the antioxidant addition into meat product formulation is more and more often applied. Natural antioxidants are in focus and new sources of the compounds are searched for.

Flax (Linum usitatissimum L.) is an important oilseed crop that contains many bioactive compounds [Toure and Xueming 2010]. Phenolic compounds are among them. Lignans, as well as phenolic acids ( $p$-coumaric, ferulic, $p$-hydroxybenzoic acids) and their glucosides, are main flaxseed phenolics. Numerous studies confirmed their antioxidant capacities [Kasote 2013]. Antioxidant activity of flaxseed extracts that contained the compounds was also investigated [Velioglu et al.1998, Anwar and Przybylski 2012, Waszkowiak et al. 2012]. However, there is a lack of accessible information about their activity against lipid oxidation in meat products.

The aim of the study was to determine the effect of ethanolic flaxseed extracts on lipid oxidation and thiamine retention, as well as lysine and methionine availability and protein digestibility, in frozen-stored meat products (pork meatballs and burgers).

\section{MATERIAL AND METHODS}

\section{Materials}

Ethanolic flaxseed extracts were prepared from the seeds of three Polish high- $\alpha$-linolenate flax varieties (IHAR, Poland): brown seeds of Szafir variety and golden seeds of Oliwin and Jantarol varieties, as it has been described below.

Partly defatted meals were prepared from the seeds [Kabirullah and Wills 1983]. Defatted flax meal was extracted twice with $60 \%$-solution of ethanol (meal to ethanol ratio of 1:7.5) under constant vigorous shaking at ambient temperature for $1 \mathrm{~h}$. The solution was separated from meal by filtration and then centrifugation (20 min, $1500 \times \mathrm{g}$; Centrifuge 5702R, Eppendorf, Germany). The supernatant was collected and ethanol was removed at $50^{\circ} \mathrm{C}$ using rotary vacuum evaporator (Buchi, Switzerland). Then supernatant was freezedried (Alpha 1-4 LSC Freeze dryer, Christ, Germany). The dried extracts were stored at $4^{\circ} \mathrm{C}$ in the dark.

\section{Meatball and burger production}

Pork (best end of neck) was minced (mesh size of $3 \mathrm{~mm}$ ) and mixed with ingredients such as water, breadcrumbs, eggs, salt and pepper [Waszkowiak et al. 2001]. The meat batter was divided into four portions; one was a control sample, while to the others the Szafir (EFE-Szafir), Oliwin (EFE-Oliwin) or Jantarol (EFE-Jantarol) ethanolic flaxseed extracts were blended in $(0.05 \%$ of meat batter).

After thorough mixing of the additives (approx. $10 \mathrm{~min}$ ) using a homogenizer meatballs and burgers were formed. The products had similar weight $(50 \mathrm{~g})$ and shape to maintain uniform cooking conditions. Meatballs were steamed for $20 \mathrm{~min}$ at $100^{\circ} \mathrm{C}$ using a convection oven (CCC series, Rational, Germany) and burgers were deep-fried for $5 \mathrm{~min}$ at $170^{\circ} \mathrm{C}$. Both products were frozen stored $\left(-18^{\circ} \mathrm{C}\right)$ in polyethylene bags for 150 days. During storage, lipid oxidation was periodically assessed by determination of peroxide and TBARS value. Moreover, thiamine retention, as well as methionine and lysine availability and protein digestibility, were monitored.

\section{Determination of lipid oxidation}

Lipids were extracted from meat products according to Folch [Folch et al. 1957] applying chloroform : methanol solvent system $(2: 1)$. The assessment of peroxide value (PV) was conducted according to ISO standard [ISO 3960:2007] in extracted lipid fraction. The results were expressed as meq. $\mathrm{O}_{2} \mathrm{~kg}^{-1}$. In turn, 2-thiobarbituric acid reactive substances (TBARS) values were determined using the Tarladgis distillation method [Tarladgis et al. 1960] modified by Pikul et al. [1989] and the results were expressed as mg malondialdehyde (MDA) $\mathrm{kg}^{-1}$.

\section{Determination of thiamine content}

Thiamine content was determined applying the thiochromium method [AOAC... 1995] with some 
modifications [Waszkowiak and Szymandera-Buszka 2007]. The results were expressed as $\mathrm{mg}$ per $100 \mathrm{~g}$ of products.

\section{Determination of amino acid availability and protein digestibility}

The effect of oxidation on protein nutritional value was investigated by monitoring of changes in available lysine and methionine, as well as protein digestibility, following procedures described by Hęś et al. [2012]. Available lysine content was determined by the method with 2,4,6-trinitrobenzenesulphonic acid (Sigma-Aldrich, Germany). Available methionine content was estimated according to spectrophotometric method after protein hydrolysis with pancreatopeptidase (Sigma-Aldrich, Germany). Both available lysine and methionine contents were expressed as mg per $100 \mathrm{~g}$ of protein. Determination of protein digestibility was carried out by the in vitro method, utilizing pepsin and tripsin (Sigma-Aldrich, Germany).

\section{Statistical analysis}

Statistical analyses were conducted using Statistica (version 9.0, StatSoft). Data were expressed as mean \pm standard deviation (SD) of two series (two independent samples) and three independent measurements for each sample $(n=6)$. The effect of treatment (addition one of EFEs and control without the addition, $L=4$ ) or storage time (days, $L=5$ ) was analysed separately. Analysis of variance (ANOVA) for a CRD (completely randomised design) experiment was carried out, and then Tukey's test at a significance level of $p \leq 0.05$ was applied to compare the means.

\section{RESULTS AND DISCUSSION}

\section{Effect on lipid oxidation}

The effect of ethanolic flaxseed extracts on lipid stability during product storage was monitored by PV and TBARS.

At the beginning of meatball storage, the rapid increase of lipid oxidation was observed (Fig. 1). The highest PVs were recorded after 60-day and 90-day storage and they rapidly decreased then. The increase of TBARS content was detected in all samples after 60 days of storage and again in the control after 120 days.
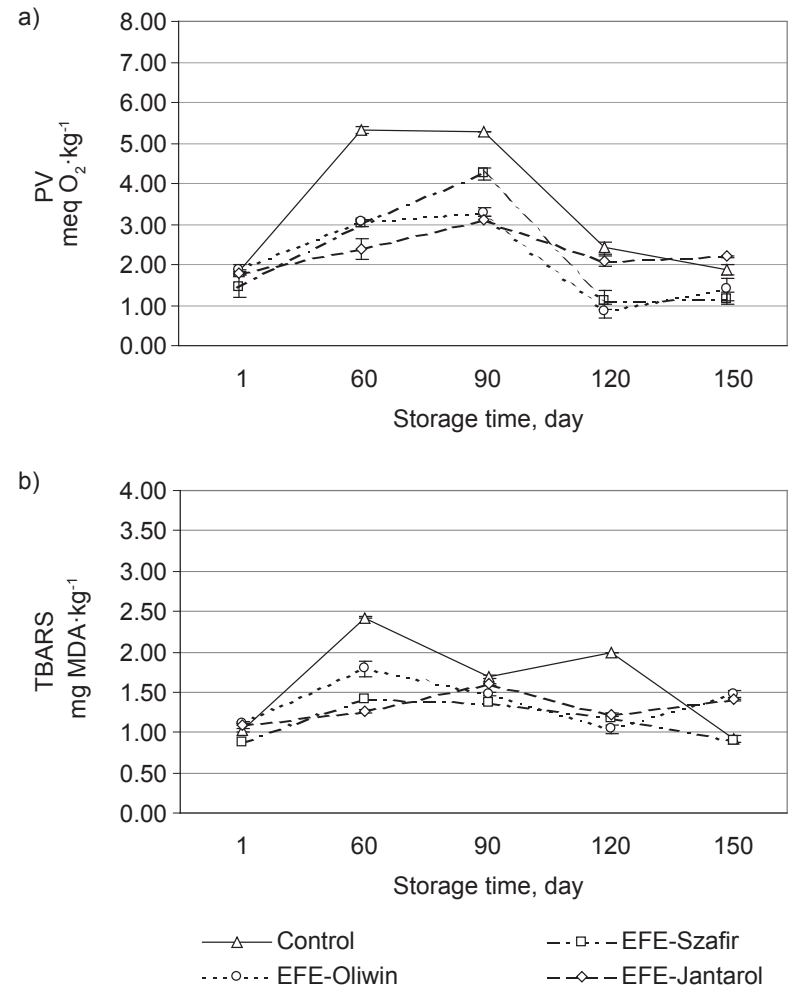

Fig. 1. Changes in peroxide value (PV) and thiobarbituric acid reactive substances (TBARS) content in frozen meatballs during 150-day storage: Control - without addition, EFE-Szafir - ethanolic extract from brown seeds of Szafir var., EFE-Jantarol - ethanolic extract from golden seeds of Jantarol var., EFE-Oliwin - ethanolic extract from golden seeds of Oliwin var. The results are presented as means $(n=6) \pm \mathrm{SD}$

The addition of ethanolic flaxseed extracts (EFEs) into meatballs significantly limited lipid oxidation. The PVs were significantly lower in the samples with EFEs, when compared to the control, up to 90 days of storage. The lowest PV was detected in the sample with EFE from Jantarol var. (EFE-Jantarol). However, the inhibition effect was diminished after 120-day storage. At the end of the storage, the effect was found only in the case of sample with EFE-Szafir. The EFE additions were also observed to decrease TBARS content in stored meatballs. Among the EFEs, the lowest TBARS was also found in the samples with EFE-Szafir. 
In frozen-stored burgers (Fig. 2), the dynamics of lipid oxidation was slower and the highest PV and TBARS in the control sample were reached after 120 days. Monitoring of lipid oxidation in stored burgers confirmed the antioxidant activity of EFEs. The peroxide values in the samples with EFEs grew up to 60 days of storage and then dropped low. After 150-day storage, the lowest PV was found in the samples with EFE-Szafir. The EFE additions also inhibited changes in TBARS content in stored burgers. The highest inhibition was observed in the samples with EFE-Jantarol at the beginning of burger storage, however, EFE-Szafir was the most effective in limiting TBARS after 120-day storage.
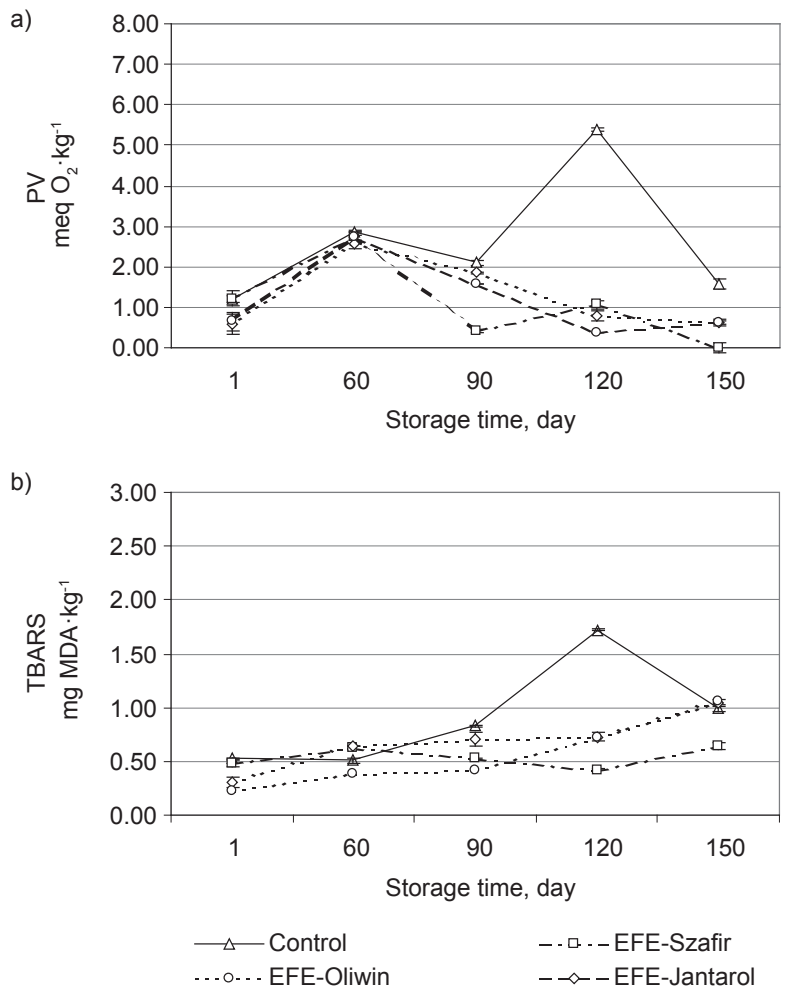

Fig. 2. Changes in peroxide value (PV) and thiobarbituric acid reactive substances (TBARS) content in frozen burgers during 150-day storage: Control - without addition, EFE-Szafir - ethanolic extract from brown seeds of Szafir var., EFE-Jantarol - ethanolic extract from golden seeds of Jantarol var., EFE-Oliwin - ethanolic extract from golden seeds of Oliwin var. The results are presented as means $(n=6) \pm \mathrm{SD}$
The similar course of changes in PV and TBARS during frozen storage of meat products (i.e. increase of the values at the beginning of storage and their decrease afterwards) was reported previously [Waszkowiak and Szymandera-Buszka 2006, Hęś et al. 2007]. It could be explained by the mechanism of lipid autoxidation [Ladikos and Lougovois 1990]. The classical mechanism is via free-radical attack. Hydroperoxides are one of the major primary oxidation products. However, they are readily decomposed to form other (secondary) oxidation products. In frozen-stored meat products, the dynamics of lipid oxidation is slowed down, but it is not stopped. Some lipid-soluble radicals may be even more stable at lower temperatures and thereby still propagate oxidation [Kanner 1994].

The results described above show an antioxidant activity of ethanolic flaxseed extracts against lipid oxidation in meat products. Phenolics, a group of flaxseed compounds, can be suspected of being involved in the action [Kasote 2013]. Previous study revealed a strong relationship between phenolic content and antioxidant activity of flaxseed extracts [Velioglu et al. 1998, Anwar and Przybylski 2012]. Secoisolariciresinol diglucoside (SDG), main flaxseed lignan, exhibited radical scavenging ability [Prasad 1997, Kitts et al. 1999]. Phenolic acids also showed antioxidant activity [Kasote 2013].

The results also indicate that the extract from brown Szafir seeds is more effective than the others. It is probably connected with the difference in chemical composition of seeds of the applied varieties. Thompson et al. [1997] found that lignan content in flaxseeds was cultivar dependent. Results of the earlier investigations concerning antioxidant capacity and composition of the ethanolic extracts [Waszkowiak et al. 2012] showed that among extracts obtained from the selected cultivars (Szafir, Oliwin and Jantarol), the highest antioxidant capacity (i.e. radical scavenging and ferric reducing activity, as well as chelating ability) was exhibited by the Szafir extract; it corresponded to the highest phenolic content in the Szafir brown seeds when compared to the seeds of golden varieties (Jantarol and Oliwin).

\section{Effect on nutritive value}

Thiamine retention was selected as one of the factors to evaluate changes in nutritional value of the meat products during storage. 
Significant effects of storage time $(P<0.01)$, as well as EFE addition $(P<0.05)$, on the changes in thiamine content were established (Table 1). Thiamine changes at storage time were found to be described well by exponential decay equation $\left(r^{2}<0.95\right)$. Therefore, half-life $\left(t_{1 / 2}\right)$ was applied to determine the effect of ethanolic flaxseed extract on the changes. Half-life was the time required for a thiamine quantity to fall by half its value at the beginning of storage.

Dynamics of changes in thiamine content was found to be higher in stored meatballs than burgers

Table 1. Changes in thiamine content in frozen meat products, mg per $100 \mathrm{~g}$

\begin{tabular}{|c|c|c|c|c|}
\hline \multirow{3}{*}{$\begin{array}{l}\text { Storage } \\
\text { time } \\
\text { days }\end{array}$} & \multicolumn{4}{|c|}{ Addition } \\
\hline & \multirow{2}{*}{$\begin{array}{l}\text { Control } \\
\text { (without } \\
\text { addition) }\end{array}$} & \multicolumn{3}{|c|}{ Ethanolic flaxseed extract $(0.05 \%)$} \\
\hline & & EFE-Szafir & EFE-Oliwin & $\begin{array}{c}\text { EFE-Jan- } \\
\text { tarol }\end{array}$ \\
\hline \multicolumn{5}{|c|}{ Meatballs } \\
\hline 1 & $0.263^{\mathrm{Aa}}$ & $0.263^{\mathrm{Aa}}$ & $0.263^{\mathrm{Aa}}$ & $0.263^{\mathrm{Aa}}$ \\
\hline 60 & $0.220^{\mathrm{Ba}}$ & $0.222^{\mathrm{Ba}}$ & $0.221^{\mathrm{Ba}}$ & $0.220^{\mathrm{Ba}}$ \\
\hline 90 & $0.198^{\mathrm{Cb}}$ & $0.201^{\mathrm{Ca}}$ & $0.204^{\mathrm{Ca}}$ & $0.202^{\mathrm{Ca}}$ \\
\hline 120 & $0.187^{\mathrm{Db}}$ & $0.191^{\mathrm{Da}}$ & $0.195^{\mathrm{Da}}$ & $0.195^{\mathrm{Da}}$ \\
\hline 150 & $0.169^{\text {Е }}$ & $0.172^{\mathrm{Ea}}$ & $0.174^{\text {Еa }}$ & $0.175^{\text {Ea }}$ \\
\hline$t_{1 / 2}$, days & $\begin{array}{c}\mathbf{2 0 3} \\
\left(r^{2}=0.989\right)\end{array}$ & $\begin{array}{c}215 \\
\left(r^{2}=0.989\right)\end{array}$ & $\begin{array}{c}\mathbf{2 2 0} \\
\left(r^{2}=0.988\right)\end{array}$ & $\begin{array}{c}\mathbf{2 2 2} \\
\left(r^{2}=0.981\right)\end{array}$ \\
\hline \multicolumn{5}{|l|}{ Burgers } \\
\hline 1 & $0.242^{\mathrm{Aa}}$ & $0.242^{\mathrm{Aa}}$ & $0.242^{\mathrm{Aa}}$ & $0.242^{\mathrm{Aa}}$ \\
\hline 60 & $0.220^{\mathrm{Ba}}$ & $0.220^{\mathrm{Ba}}$ & $0.220^{\mathrm{Ba}}$ & $0.219^{\mathrm{Ba}}$ \\
\hline 90 & $0.192^{\mathrm{Cb}}$ & $0.199^{\mathrm{Ca}}$ & $0.198^{\mathrm{Ca}}$ & $0.200^{\mathrm{Ca}}$ \\
\hline 120 & $0.185^{\mathrm{Db}}$ & $0.190^{\mathrm{Da}}$ & $0.192^{\mathrm{Da}}$ & $0.190^{\mathrm{Da}}$ \\
\hline 150 & $0.157^{\text {Eb }}$ & $0.165^{\mathrm{Ea}}$ & $0.162^{\text {Ea }}$ & $0.165^{\mathrm{Ea}}$ \\
\hline$t_{1 / 2}$, days & $\begin{array}{c}\mathbf{2 2 0} \\
\left(r^{2}=0.959\right)\end{array}$ & $\begin{array}{c}\mathbf{2 4 3} \\
\left(r^{2}=0.969\right)\end{array}$ & $\begin{array}{c}\mathbf{2 3 7} \\
\left(r^{2}=0.962\right)\end{array}$ & $\begin{array}{c}\mathbf{2 4 4} \\
\left(r^{2}=0.970\right)\end{array}$ \\
\hline
\end{tabular}

Means $(n=6)$ indicated with different lowercase letters in the same line (addition effect) and uppercase letters in the same column (storage time effect) are significantly different (oneway ANOVA, Turkey test, $P=0.05$ ); $t_{1 /}$ - half-life, i.e. time (days) in which a initial thiamine content falls by half (correlation coefficient $r^{2} ; P<0.001$ ). (lower half-life values). However, the final thiamine retentions after 150-day storage of both products were similar (i.e. $64 \%$ and $65 \%$ for the meatball and burger control samples, respectively). The results may be explained by formation of the so-called "skin" on burgers surface during deep-frying that probably limited thermal drip, as well as thiamine losses during defrosting [Szymandera-Buszka et al. 2011].

The significant effect of EFE addition on thiamine retention was found after 90-day storage of the meat products (Table 1). Slower dynamics of thiamine changes was observed in all meatball and burger samples with EFEs when compared to the controls, irrespective of extract type.

Earlier studies on changes in thiamine content in stored meat and meat products showed that formation of lipid oxidation products affected thiamine retention [Szymandera-Buszka and Waszkowiak 2005 a]. Disadvantageous effect of lipid oxidation products on thiamine retention may be connected with thiamine sensibility to redox factors that open its thiazole ring [Dwivedi and Arnold 1971, 1972]. The protective action of antioxidants against thiamine losses and its relation to oxidation product formation was previously reported [Szymandera-Buszka 2003, Szymandera-Buszka and Waszkowiak 2005 b, Waszkowiak and Szymandera-Buszka 2006].

Protein oxidation-induced changes may decrease the bioavailability of amino acid residues and modify the digestibility of proteins [Lund et al. 2011]. The changes negatively affect nutritional value of meat proteins. In the study, the effect of lipid oxidation on protein nutritional value during meat product storage was assessed by monitoring of changes in available lysine and methionine content, as well as protein digestibility.

Significant decrease in available lysine $(P<0.05)$ was found after 150-day storage of meatballs and burgers (Table 2). At the end of storage, the lysine availability fell down by $16 \%$ in the control samples, both meatballs and burgers. Higher lysine availability was found in samples with EFEs. In stored meatballs, all flaxseed extracts limited changes in lysine availability. In burgers, however, only EFE-Szafir and EFE-Oliwin showed the protective effect.

After 150-day storage, the methionine availability decreased by $34 \%$ and $38 \%$ in the meatball and burger 
Waszkowiak K., Szymandera-Buszka K., Hęś M., 2014. Effect of ethanolic flax (Linum usitatissimum L.) extracts on lipid oxidation and changes in nutritive value of frozen-stored meat products. Acta Sci. Pol., Technol. Aliment. 13(2), 135-144.

Table 2. Changes in lysine and methionine availability in frozen meat products, $\mathrm{g} 100 \mathrm{~g}^{-1}$ of protein

\begin{tabular}{lcccc}
\hline \multirow{2}{*}{$\begin{array}{c}\text { Storage } \\
\text { time } \\
\text { (days) }\end{array}$} & $\begin{array}{c}\text { Control } \\
\text { (without } \\
\text { addition) }\end{array}$ & EFE-Szafir & EFE-Oliwin & $\begin{array}{c}\text { EFE-Jan- } \\
\text { tarol }\end{array}$ \\
\cline { 3 - 5 } & Eddition \\
\hline $\begin{array}{l}\text { Available lysine } \\
\text { Meatballs }\end{array}$ & & & \\
\hline 1 & $8.77^{\mathrm{Ba}}$ & $9.65^{\mathrm{Ba}}$ & $8.90^{\mathrm{Aa}}$ & $9.37^{\mathrm{Aa}}$ \\
150 & $7.37^{\mathrm{Aa}}$ & $8.29^{\mathrm{Ab}}$ & $8.04^{\mathrm{Ab}}$ & $8.48^{\mathrm{Ab}}$ \\
\hline Burgers & & & & \\
\hline 1 & $9.27^{\mathrm{Ba}}$ & $8.82^{\mathrm{Aa}}$ & $9.10^{\mathrm{Ba}}$ & $8.79^{\mathrm{Ba}}$ \\
150 & $7.79^{\mathrm{Aa}}$ & $8.35^{\mathrm{Ab}}$ & $7.87^{\mathrm{Ab}}$ & $7.74^{\mathrm{Aa}}$ \\
\hline $\begin{array}{l}\text { Available } \\
\text { Methionine }\end{array}$ & & & \\
\hline 1 & & & & \\
\hline 150 & $1.85^{\mathrm{Ba}}$ & $1.83^{\mathrm{Ba}}$ & $1.77^{\mathrm{Ba}}$ & $1.79^{\mathrm{Ba}}$ \\
\hline Burgers & & $1.22^{\mathrm{Aa}}$ & $1.27^{\mathrm{Aa}}$ & $1.21^{\mathrm{Aa}}$ \\
\hline 1 & $2.08^{\mathrm{Ba}}$ & $2.07^{\mathrm{Ba}}$ & $2.04^{\mathrm{Ba}}$ & $1.95^{\mathrm{Ba}}$ \\
150 & $1.29^{\mathrm{Aa}}$ & $1.40^{\mathrm{Ab}}$ & $1.35^{\mathrm{Aab}}$ & $1.32^{\mathrm{Aa}}$ \\
\hline
\end{tabular}

Means $(n=6)$ indicated with different lowercase letters in the same line (addition effect) and uppercase letters in the same column (storage time effect) are significantly different (oneway ANOVA, Turkey test, $P=0.05$ ).

control samples, respectively (Table 2). The effect of EFE addition on changes in available methionine was limited. The absence of the EFE effect on methionine availability was shown in meatballs. In burgers, only EFE of Szafir var. significantly protected against the changes.

The 150-day frozen storage of samples also affected protein digestibility (Fig. 3). The highest changes in digestibility were found in the control samples ( $10 \%$ and $8 \%$ in the case of meatball and burger control, respectively). The protein digestibility was significantly higher in stored samples with EFEs when compared to the controls, irrespectively of extract type (flax variety); it amounted to $4 \%$.
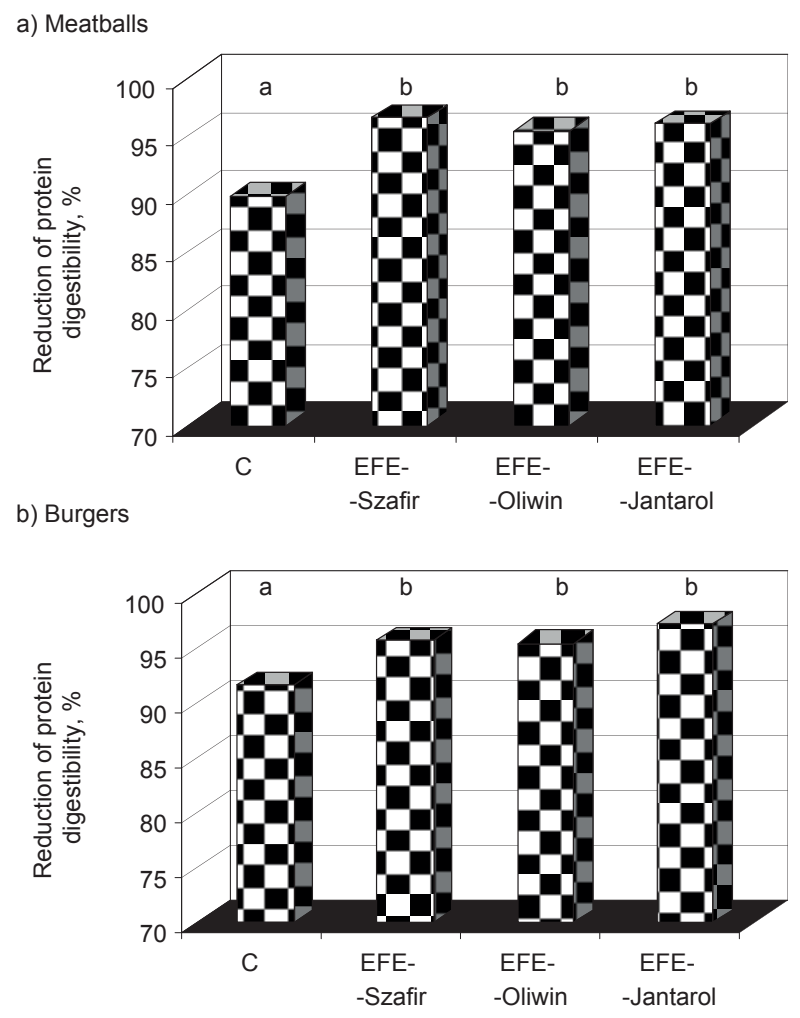

Fig. 3. Changes in protein digestibility after 150-day frozen storage of meat products (initial sample digestibility is equal 100\%): C - without addition, EFE-Szafir - ethanolic extract from brown seeds of Szafir var., EFE-Jantarol - ethanolic extract from golden seeds of Jantarol var., EFE-Oliwin - ethanolic extract from golden seeds of Oliwin var. Mean values (bars) with different letters are significantly different (one-way ANOVA, Turkey test, $P=0.05$ )

The observed decrease of protein nutritional value in frozen-stored meat products confirmed the results of previous study [Korczak et al. 2004, Hęś et al. 2007]. It seems to be an effect of lipid oxidation, as well as reaction that occurs then between amino acid residues and oxidation products [Hęś et al. 2012]. Reduction in available lysine can be caused by blocking of the $\varepsilon$-amino groups. In turn, changes in available methionine can be connected with direct oxidation and methionine sulphoxide or sulphone formation [Zhang et al. 2013]. Oxidation of proteins can also induce protein polymerisation and aggregation, and thus, change their digestibility and affect the nutritional value of 
meat products [Morzel et al. 2006]. Protein oxidation can change the inter- and intermolecular interactions within protein and influence its conformation. Generally, the oxidation-induced changes can increase protein surface hydrophobicity, as well as form inter- and intra-cross-linkage, which can lead to protein aggregation. Some amino acid are involved in protein crosslinkage formation [Zhang et al. 2013]: sulphydryl groups and tyrosine residues can lead to the generation of disulphide and dityrosine bonds, respectively; carbonyl derivatives arising from direct and indirect oxidation can react with lysine amino acid groups within a protein or between different proteins, leading to protein cross-linkage.

Pokorny and Davidek [1979] reported that primary products of lipid oxidation (hydroperoxides) initiated the protein cross-linking, as well as amino acid oxidation and transformation of amino into imino groups. Secondary oxidation products (aldehydes) took part in protein cross-linking and blocking of amino acid functional groups [Esterbauer et al. 1991], e.g. they formed Schiff bases with the amino group of lysine. Amino acids were more susceptible to damage by secondary products of lipid oxidation when compared to primary ones [Zhang et al. 2013].

As in the case of thiamine retention, limiting of changes in protein nutritional value by ethanolic flaxseed extracts were probably connected with their protective action against lipid oxidation. Some ethanolic plant extracts contained phenolic compounds were also reported to inhibit both lipid oxidation and deterioration of nutritional quality of meat proteins [Hęś et al. 2007, 2009, Ganhao et al. 2010]. Phenolic compounds were suggested to act against oxidationinduced damage of myofibrillar protein by two mechanisms: metal chelation (leading to inactivation of nonheme iron prooxidant effect) and radical scavenging (they could be scavengers of iron- and lipid-mediated reactive oxidant species) [Estevez et al. 2008]. As it has been maintained in the above section of manuscript, the EFEs had both radical scavenging and chelating ability [Waszkowiak et al. 2012]. However, antioxidant efficiency of the phenolic compounds in meat products depends on numerous factors, e.g. their structure, localization and interaction with meat proteins [Estevez and Heinonen 2010, Lund et al. 2011].
Results of the study show a decrease in available methionine during storage of meat products despite the clear protective effect of EFEs against oxidation. It was in agreement with the results reported by Jongberg et al. [2011] that described a decrease of carbonyl group and disulphide cross-linkage formation (i.e. markers of protein oxidation) in myosin heavy chain in stored beef patties contained white grape phenolic extract, when compared to control without the addition; however, similar losses of thiol groups was detected in both samples. Therefore, an overall antioxidant effect of the phenolics was suggested despite the increased losses of thiol groups and the phenomena was explained by interaction between quinones (oxidized derivatives of phenolic compounds) and myofibrillar protein thiol groups, leading to formation of thiol-quinone adducts. Alegria et al. [2008] reported that the above-maintained adducts were also identified for BSA in presence of cyclolignanic quinones. The interaction between quinones and thioether group of methionine [Sosulski 1979] may also explain the decrease of available methionine content detected in the samples with EFEs. However, the interaction between phenolic compounds and proteins in muscle food is still not completely understood and needs further study.

\section{REFERENCES}

Alegria A.E., Sanchez-Cruz P., Kumar A., Garcia C., Gonzalez F.A., Orellano A., Zayas B., Gordaliz M., 2008. Thiols oxidation and covalent binding of BSA by cyclolignanic quinones are enhanced by the magnesium cation. Free Radic. Res. 42, 70-81.

Anwar F., Przybylski R., 2012. Effect of solvent extraction on total phenolics and antioxidant activity of extracts from flaxseed (Linum usitatissimum L.). Acta Sci. Pol., Technol. Aliment. 11, 293-301.

AOAC Official Method 942.23, 1995. Thiamine (vitamin B1) in food. In: AOAC Official Method of Analysis. Vol. 2. Ed. P. Cunniff. AOAC Darlington, VA, 6-7.

Dwivedi B.K., Arnold R.G., 1971. Hydrogen sulfide from heat degradation of thiamine. J. Agric. Food Chem. 19, 923-926.

Dwivedi B.K., Arnold R.G., 1972. Chemistry of thiamine degradation: 4-methyl-S( $\beta$-hydroksyethyl)thiazole from thermally degradation thiamine. J. Food Sci. 37, 689-692. 
Waszkowiak K., Szymandera-Buszka K., Hęś M., 2014. Effect of ethanolic flax (Linum usitatissimum L.) extracts on lipid oxidation and changes in nutritive value of frozen-stored meat products. Acta Sci. Pol., Technol. Aliment. 13(2), 135-144.

Esterbauer H., Schaur R.J., Zollner H., 1991. Chemistry and biochemistry of 4-hydroxynonenal, malonaldehyde and related aldehydes. Free Radical Biol. Med. 11, 81-128.

Estevez M., Heinonen M., 2010. Effect of phenolic compounds on the formation of $\alpha$-aminoadipic and $\gamma$-glutamic semialdehydes from myofibrillar proteins oxidized by copper, iron, and myoglobin. J. Agric Food Chem. 58, $4448-4455$

Estevez M., Kylli P., Puolanne E., Kivikari R., Heinonen M., 2008. Oxidation of skeletal muscle myofibrillar proteins in oil-in-water emulsion: interaction with lipids and effect of selected phenolic compounds. J. Agric Food Chem. 56, 10933-10940.

Folch J., Lees M., Sloane S.G.H., 1957. A simple method for the isolation and purification of total lipids from animal tissues. J. Biol. Chem. 226, 497-509.

Friedman M., 1996. Nutritional value of proteins from different food sources. A review. J. Agric. Food Chem. 44, 6-29.

Ganhao R., Morcuende D., Estevez M., 2010. Tryptophan depletion and formation of $\alpha$-aminoadipic and $\gamma$-glutamic semialdehydes in porcine burger patties with phenolic-rich-fruit extracts. J. Agric Food Chem. 58, 3541-3548.

Hęś H., Waszkowiak K., Szymandera-Buszka K., 2012. The effect of iodine salts on lipid oxidation and changes in nutritive value of protein in stored processed meats. Meat Sci. 90, 139-143.

Hęś M., Korczak J., Gramza A., 2007. Changes of lipid oxidation degrees and their influence on protein nutritive value of frozen meat products. Pol. J. Food Nutr. Sci. $57,3,323-328$.

Hęś M., Korczak J., Pyrcz J., Kowalski R., 2009. Influence of lipid stabilization on the retention of available lysine and methionine in stored raw polish sausage. Żywn. Nauka Techn. Jakość 4, 65, 19-25.

ISO 3960:2007 (corrected version, 2009). Animal and vegetable oils and fats. Determination of peroxide value.

Jongberg S., Skov S.H., Torngren M.A., Skibsted L.H., Lund M.N., 2011. Effect of white grape extract and modified atmosphere packing on lipid and protein oxidation in chill stored beef patties. Food Chem. 128, 276-283.

Kabirullah M., Wills R.B.H., 1983. Characterization of sunflower protein. J. Agric. Food Chem. 31, 953-956.

Kanner J., 1994. Oxidative processes in meat and meat products: quality implications. Meat Sci. 36, 169-189.

Kasote D.M., 2013. Flaxseed phenolic as natural antioxidants. Int. Food Res. J. 20, 1, 27-34.
Kitts D.D., Yuan Y.V., Wijewickreme A.N., Thompson L.U., 1999. Antioxidant activity of the flaxseed lignan secoisolariciresinol diglycoside and its mammalian lignan metabolites enterodiol and enterolactone. Mol. Cell. Biochem. 202, 91-100.

Korczak J., Hęś M., Gramza A., Jędrusek-Golińska A., 2004. Influence of fat oxidation on the stability of lysine and protein digestibility in frozen meat products. EJPAU 7 (1), \#2, 1-13, [online], www.ejpau.media.pl/ food/volume7/issue 1/.

Ladikos D., Lougovois V., 1990. Lipid oxidation in muscle food: a review. Food Chem. 35, 295-314.

Lund M.N, Heinonen M., Baron C.P., Estevez M., 2011. Protein oxidation in muscle food: A review. Mol. Nutr. Food Res. 55, 83-95.

Morzel M., Gatellier P.H., Sayd T., Renerre M., Laville E., 2006. Chemical oxidation in decreases proteolytic susceptibility of skeletal muscle proteins. Meat Sci. 73, 536-543.

Pikul J., Leszczyński D.E., Kummerow F.A., 1989. Evaluation of tree modified TBA methods for measuring lipid oxidation in chicken meat. J. Agric. Food Chem. 37, 1309-1313.

Pokorny J., Davidek J., 1979. Influence in interactions of proteins with oxidized lipids on nutrition and sensory value of food. Acta Aliment. Pol. 5, 87-95.

Prasad K., 1997. Hydroxyl radical-scavenging property of secoisolariciresinol diglucoside (SDG) isolated from flax-seed. Mol. Cell. Biochem. 168, 117-123.

Sosulski F., 1979. Organoleptic and nutritional effects of phenolic compounds on oilseed protein products: a review. JAOCS 56, 711-715

Szymandera-Buszka K., 2003. The qualitative and quantitative changes of thiamine in sterilized pork in the presence of selected technological additives. Pol. J. Food Nutr. Sci. 53, 4, 59-62.

Szymandera-Buszka K., Waszkowiak K., Hęś M., JędrusekGolińska A., 2011. The effect of the application of protein and cellulose preparations as iodine carriers on stability of thiamine in processed meats. Nauka Przyr. Technol. 5, 1, 1-10.

Szymandera-Buszka K., Waszkowiak K., 2005 a. The effect of oxidized soybean oil at variable reaction of the medium on thiamine hydrochloride quantitative changes. Żyw. Człow. Metab. 32, 917-921.

Szymandera-Buszka K., Waszkowiak K., 2005 b. Assessment of potential usability of casein hydrolysate and rosemary extract as substances protecting thiamine hydrochloride 
Waszkowiak K., Szymandera-Buszka K., Hęś M., 2014. Effect of ethanolic flax (Linum usitatissimum L.) extracts on lipid oxidation and changes in nutritive value of frozen-stored meat products. Acta Sci. Pol., Technol. Aliment. 13(2), 135-144.

in the presence of soybean oil. Żyw. Człow. Metab. 32, 912-916.

Tarladgis B.G., Watts B.M., Younathan M.T., 1960. A distillation method for the quantitative determination of malonaldehyde in rancid food. J. Am. Oil Chem. Soc. $37,44-48$

Thompson L.U., Rickard S.E., Chung F., Kenaschuk E.O., Obermeyer W.R., 1997. Variability in anticancer lignan levels in flaxseed. Nutr. Cancer 27, 26-30.

Toure A., Xueming X., 2010. Flaxseed lignans: source, biosynthesis, metabolism, antioxidant activity, bio-active components and health benefits. CRFSFS 9, 261-269.

Velioglu Y.S., Mazza G., Gao L., Oomah B.D., 1998. Antioxidant activity and total phenolics in selected fruits, vegetables and grain products. J. Agric. Food Chem. 46, 4113-4117.

Wąsowicz E., Gramza A., Hęś M., Jeleń H.H., Korczak J., Małecka M., Mildner-Szkudlarz S., Rudzińska M., Samotyja U., Zawirska-Wojtasiak R., 2004. Oxidation of lipids in food. Pol. J. Food Nutr. Sci. 54 (13), 87-100.

Waszkowiak K., Gliszczyńska-Świgło A., Skręty J., 2012. Antioxidant activity of extracts from polish flax varieties.
In: 10th Euro Fed Lipid Congress. 23-26 September, Krakow. Book of Abstracts: Fats, Oils and Lipids: from Science and Technology to Health, 286

Waszkowiak K., Górecka D., Janitz W., 2001. Wpływ preparatu błonnika pszennego na jakość potraw mięsnych [Influence of wheat dietary fibre on the quality of meat dishes]. Żywn. Nauka Techn. Jakość 28, 53-61 [in Polish].

Waszkowiak K., Szymandera-Buszka K., 2006. Wpływ obróbki termicznej potraw na efektywność przeciwutleniającą ekstraktu rozmarynu [The influences of thermal treatment of dishes from minced pork meat on antioxidant action of rosemary extract]. Bromat. Chem. Toksykol. 38, 467-471 [in Polish].

Waszkowiak K., Szymandera-Buszka K., 2007. Effect of collagen preparation used as carriers of potassium iodide on retention of iodine and thiamine during cooking and storage of pork meatballs. J. Sci. Food Agric. 87, 1473-1479.

Zhang W., Xiao S., Ahn D.U., 2013. Protein oxidation: basic principles and implication for meat quality. Critical Rev. Food Sci. Nutr. 53, 1191-1201.

\section{WPLYW EKSTRAKTÓW ETANOLOWYCH Z NASION LNU (LINUM USITATISSIMUM L.) NA UTLENIANIE LIPIDÓW ORAZ ZMIANĘ WARTOŚCI ODŻYWCZEJ PRODUKTÓW MIĘSNYCH PRZECHOWYWANYCH ZAMRAŻALNICZO}

\section{STRESZCZENIE}

Cel. Nasiona lnu (Linum usitatissimum L.) są ważnym źródłem związków fenolowych, a szczególnie lignanów. Wcześniejsze badania wykazały, że ekstrakty z nasion lnu, zawierające te związki, mają właściwości przeciwutleniające. Jednakże brak danych dotyczących ich aktywności przeciwutleniającej po dodaniu do żywności. Dlatego postanowiono ocenić wpływ ekstraktów etanolowych z nasion lnu (EFE) na stabilność lipidów oraz zmiany wartości odżywczej mrożonych produktów mięsnych (pulpetów i kotletów mielonych). Materiały i metody. Ekstrakty etanolowe otrzymano z trzech odmian nasion lnu (Szafir, Oliwin, Jantarol) wyhodowanych i uprawianych w Polsce. Podczas 150 dni przechowywania zamrażalniczego okresowo oznaczano stopień utlenienia lipidów (liczba nadtlenkowa i zawartość TBARS), retencję tiaminy oraz dostępnej lizyny i metioniny, a także oceniono strawność białek produktów mięsnych.

Wyniki. Dodatek EFE istotnie zmniejszył utlenianie lipidów w obu przechowywanych produktach. EFE otrzymany z brązowonasiennej odmiany Szafir był efektywniejszy niż ekstrakty z obu pozostałych odmian żółtonasiennych (Oliwin i Jantarol). Ponadto badane ekstrakty ograniczyły straty tiaminy i dostępnej lizyny oraz zmiany strawności białek podczas przechowywania. Wpływ obecności EFE na zmiany zawartości dostępności metioniny był jednak ograniczony.

Wnioski. Ekstrakty etanolowe z nasion lnu wykazują aktywność przeciwutleniającą w przechowywanych produktach mięsnych. Dlatego z powodzeniem mogłyby zostać wykorzystane $\mathrm{w}$ produkcji przetworów mięsnych w celu ograniczania procesu utleniania oraz jego negatywnego wpływu na wartość odżywczą tych wyrobów. Należy jednak uwzględnić, że uzyskiwany efekt przeciwutleniający ekstraktów może być 
Waszkowiak K., Szymandera-Buszka K., Hęś M., 2014. Effect of ethanolic flax (Linum usitatissimum L.) extracts on lipid oxidation and changes in nutritive value of frozen-stored meat products. Acta Sci. Pol., Technol. Aliment. 13(2), 135-144.

uzależniony od składu chemicznego surowca, z którego będą pozyskane (odmiany nasion). Aspekt ten wymaga dalszych badań.

Słowa kluczowe: nasiona lnu, ekstrakt etanolowy, utlenianie lipidów, retencja tiaminy, wartość odżywcza białek

Received - Przyjęto: 1.10.2013

Accepted for print - Zaakceptowano do druku: 22.01.2014

For citation - Do cytowania

Waszkowiak K., Szymandera-Buszka K., Hęś M., 2014. Effect of ethanolic flax (Linum usitatissimum L.) extracts on lipid oxidation and changes in nutritive value of frozen-stored meat products. Acta Sci. Pol., Technol. Aliment. 13(2), 135-144. 